научно-технической и экономической политики, простота в управлении, а также возможности в привлечении перспективных изобретателей к деятельности.

5. Статус успешного венчура на рынке позволяет избежать сомнений потенциальных инвесторов.

Так венчур, создаваемый для разработки инновации для развития одной крупной компании может продолжить свое существование в рамках другой компании, претерпев некоторые изменения.

Предлагается несколько конкретизировать данную венчурную стратегию. Наиболее эффективными формами, на наш взгляд, являются:

- стратегия поглощения венчура с целью перепрофилирования и интеграции в компанию;

- стратегия поглощения нескольких родственных вечнуров с их дальнейшим слиянием и интеграцией в компанию.

Венчурная фирма каждого из представленных выше типов создается обычно небольшим кругом единомышленников - изобретателей, инженеров, менеджеров с опытом работы в лабораториях крупных фирм. По степени ответственности и организационно-правовым формам венчурные фирмы бывают частными предприятиями, акционерными компаниями и хозяйственными обществами.

Имеются данные, свидетельствующие об эффективности малых венчурных компаний в области внедрения инноваций. Национальный научный фонд США подвел некоторые результаты, касающиеся фирм различных форм хозяйствования, осуществляющих инновационную деятельность. Так, на каждый доллар вложенный в НИОКР малые компании, чья численность не превышает 100 чел., осуществляли в 4 и в 24 раза больше нововведений, чем компании с числом работников от 100 до 1000 чел. и компании с занятостью свыше 1000 чел. соответственно. А также, темпы нововведений у малых фирм на треть выше, чем у крупных, а в среднем небольшим фирмам требуется 2,22 г., чтобы выйти на рынок со своими нововведениями, в то время как крупным - 3,05 г. [10]

Таким образом, в современных условиях для успешного функционирования корпорациям необходимо использовать все возможные преимущества венчурных стратегий. Таким образом, на сегодняшний день можно считать актуальными предложенные нами стратегии создания внутренних венчуров и поглощения венчуров с сохранением ими предпринимательской независимости.

\section{Список использованной литературы}

1. Гражданский кодекс Российской Федерации. Часть первая : федеральный закон от 30 ноября 1994 года № 51-Ф3 (ред. от 31 января 2016 года) // Российская газета. - 1994. - 08 дек.

2. Бурдыкова Н. А. Венчур использовал кризис/ Н. А Бурдыкова // Эксперт Юг. 2009. - № 46-47 (85). - C. 23-25.

3. Инновационный менеджмент: Концепции, многоуровневые стратегии и механизмы инновационного развития: учеб. пособие / под ред. В. М. Аньшина, А. А. Дагаева. - 3-е изд., перераб., доп. Москва: Дело, 2007. - С. 370.

4. Камалов А. В. Венчурное финансирование - инструмент развития инновационной экономики //Вестник Финансового университета. - 2011. - № 2. - C. 47-49.

5. Кокурин Д.И. Инновационная деятельность. - Москва, 2001

6. Ныров А. А. Управление развитием венчурного инвестирования в России: дис. ... канд. эконом. наук. - Москва, 2008. - 168 с.

7. Прохоров А. Ю. Венчурное финансирование как перспективный метод привлечения инвестиций / А. Ю. Прохоров // Экономика, предпринимательство и право. - 2013. - № 3 (20). - С. 11-12.

8. Чжэн Ж. Сущность и структура системы управления внутренним венчуром / Ж. Чжэн // Гуманитарные исследования Внутренней Азии. 2016. T. 3. - С. 76-81.

9. Чистякова О.В. Организационные аспекты взаимодействия корпорации с внутренними венчурами и спинаутами/ О. В. Чистякова //Известия Иркутской государственной академии. -2011 , - №4, C. 102.

10. Яллай В. Я. Управление инновациями в малом и среднем бизнесе / В. Я. Яллай // В сборнике: Экономические аспекты регионального развития: история и современность материалы VI Всероссийской научно-практической конференции с международным участием. - 2015. - С. 274-276. - С. 276.

UDC 339.13.021:004(477)

AORCID 0000-0001-6569-9738

\title{
PROSPECTS AND ROLE OF UKRAINE IN GLOBAL CRYPTOINDUSTRY
}

\author{
Opanasiuk Vitalii \\ PhD in Economics, Associate Professor, \\ Kyiv International University, Kyiv \\ DOI: 10.31618/ESU.2413-9335.2019.8.61.68
}

\section{ABSTRACT.}

The article is devoted to research and comparative analysis of the possibilities and current state of the investment climate of the countries of the world and Ukraine. The article suggests the directions of specialization and cooperation of Ukraine in the market of the global crypto industry. 
АННОТАЦИЯ.

Статья посвящена исследованию и сравнительному анализу возможностей и современного состояния инвестиционного климата стран мира и Украины. В статье предложены направления специализации и кооперации Украины на рынке глобальной крипто индустрии.

Keywords: interstate cooperation, specialization, crypto industry, mining, crypto investment.

Ключевые слова: межгосударственная кооперация, специализация, крипто индустрия, майнинг, криптоинвестиции.

Actuality of the problem. The relevance of the topic of specialization and cooperation of Ukraine in the world crypt industry is determined by the significant opportunities that this young industry opens. In addition, the willingness of private investors to risk higher than the classical investment make Ukraine one of the few areas that has concentrated unprofessional and professional investors. This gives some benefits to the start of the crypt industry development: to be the first in going through the formation of an expert layer, the first in forming a group of professional investors, to be the first in exploring the impact of cryptographic investment on GDP and competitiveness indices.

The main task is to determine the prospects, place and specialization of Ukraine in the interstate cooperation point of view of the crypto industry.

Research methods. Methodological and informational basis of work are scientific works, materials of periodicals, Internet resources, legal acts.

In the course of the research, methods of structural-logical analysis, comparison and generalization were used.

Analysis of research and publications. Modern Ukrainian specialists are studying the topic of economics transformation and place in Ukraine under the conditions of the scientific and technological revolution 4.0. The most widespread are the research of Baselevich VD, Ilyin VV, Belikov VS, Grushchinsky N.M.

Results. In countries that take advantage of the opportunities and benefits of participating in the global division of labor, there is usually a much higher rate of economic and social development. Compared to the classic, historically formed investment markets, the crypt industry has high risk and multiplier rates.

Cryptindustry, as the phenomenon of the last five years, goes through the stages of maturing, as was the case of classic investment markets: real estate, securities, currencies and intangible assets. The peculiarity of cryptoindustry can be called incredible dynamics and the speed of transformations. Some areas of investment in the crypt industry do not have time to work out the planned ROIC, as it is necessary to make a capital transfer through the closing of the niche.

For a long time, institutional investors have bypassed the crypt industry, citing the lack of a clear regulatory system. According to a Thompson Reuters analyst, $20 \%$ of the 400 surveyed financial companies plan to invest in cryptotechnology. Білл Бархідт 3 American Express confirmed the interest of hedge funds and wealthy individuals in the cryptography because of its volatility.

The emergence of organizations that are peculiar to the traditional financial sector is creating more and more trust in institutional investors. Lloyd'sofLondon, the oldest British insurance company, has begun cooperation with the United States Custodian Service KingdomTrust. More than 100 thousand Clients hold cryptographic assets in 30 popular currencies for a total amount of more than $\$ 12$ billion in cold storage services.

Coinbase is in line with its leadership position and seeks to create a safe infrastructure that is traditional for the traditional financial system. About the first deposits worth more than $\$ 20$ billion on the Coinbase Custody service reported on Twitter on July 2nd.

The Japanese bank Nomura, together with the manufacturer of hardware wallets Ledger and investment manager Global Advisors are already developing a crypto-currency depository, the investment bank Goldman Sachs while considering such an opportunity, but notes the growing interest of its customers in digital assets.

Customers Goldman Sachs and the bank itself are clearly counting on an offensive so-called "cryptcurrency spring." Futures contracts provide for the sale and purchase of an asset at a pre-determined price on a pre-set date. The basis of pricing in the market bitcoinfutures are spot prices on cryptoexchange trading, trading in real time.

The popularity of futures contracts, which began trading in December 2017 at the Chicago Commodity Exchange SME and the Chicago Exchange of its options, prompted a number of companies such as applying for the launch of Bitcoins-ETFs. Thus, the market of digital currencies is waiting for a new strong recovery, the driver of which should be the inflow of funds from institutional investors. But the question "why the kriptoindustriya can and should interest investors" remains open.

Despite constant criticism from JP Morgan and GoldmanSachs, both financial groups are trying to work with cryptic currency. And every month, more and more. Only the first one does this secretly, through a British subsidiary, which is a market maker on European crypto exchanges, while the latter openly develop their solutions based on blockade and cryptology. They actively interact with the authorities, and therefore their positions are synchronous.

On the one hand, global players want to engage in the emergence of a young and promising industry; on the other hand, they fear involvement in unregulated financial transactions, anonymous transactions [1, p. 9].

If you can name the classic investment market in short:

- financial capital;

- securities;

- material funds;

- intangible assets;

- human capital;

- venture capital; 
- real estate;

- precious metals;

- other derivatives.

In the cryptography industry, by analogy, the following main segments can be called for investment:

- cryptographic (mono or multi-briefcases of tokens and codins). Near by analogy with the capital market and securities in a mixed form;

- ICO market (initial coin offering), close to the IPO (initial public offering) market;

- landing - support for the service or work of the blockade of infrastructure. Close in essence to investing in major funds;

- mineing of a bullet - is close in essence to mutual investment funds;

- cryptographic funds - close in essence to investing in venture capital or other high-risk assets.

Obviously, there is some analogy with classical investment, but there are also fundamental differences:

1. The greatest value of the kriptoindustry is decentralization and, as a consequence, the reliability and stability of the infrastructure. And it is precisely this value that does not possess anyone, but all the members of the block-chay own one or another minority. Although there are exceptions.
2. The term of investment. The fact that in classical investment is called "medium-term investment" with a horizon of 3-5 years, in the cryptindustry, due to her youth, is a long term almost beyond the horizon of planning. 3. Specialization and cooperation. In the classical scientific economic literature, the process of integration begins with the economic andregulation of subjects, after the sectoral, cross-border cooperation, after that intergovernmental, interregional and global [2, p. 173].

Market cryptindustry passes at an accelerated pace obligatory stages, which went into the stock market for decades, and in the capital market and real estate of the millennium:

- stage of origin;

- stage of chaotic / speculative expansion;

-the stage of super-risks and super-profits;

- stage of monopolization;

- stage of regulation, demonopolization, socialization

The stage of integration and forecastingIf in the classical economy, the basic indicators of ROIC is 5$25 \%$, then for the crypto industry, this indicator is 20 $1600 \%$ (Fig. 1).

For comparison, look at ROIC in the crypt industry sectors like ICO.

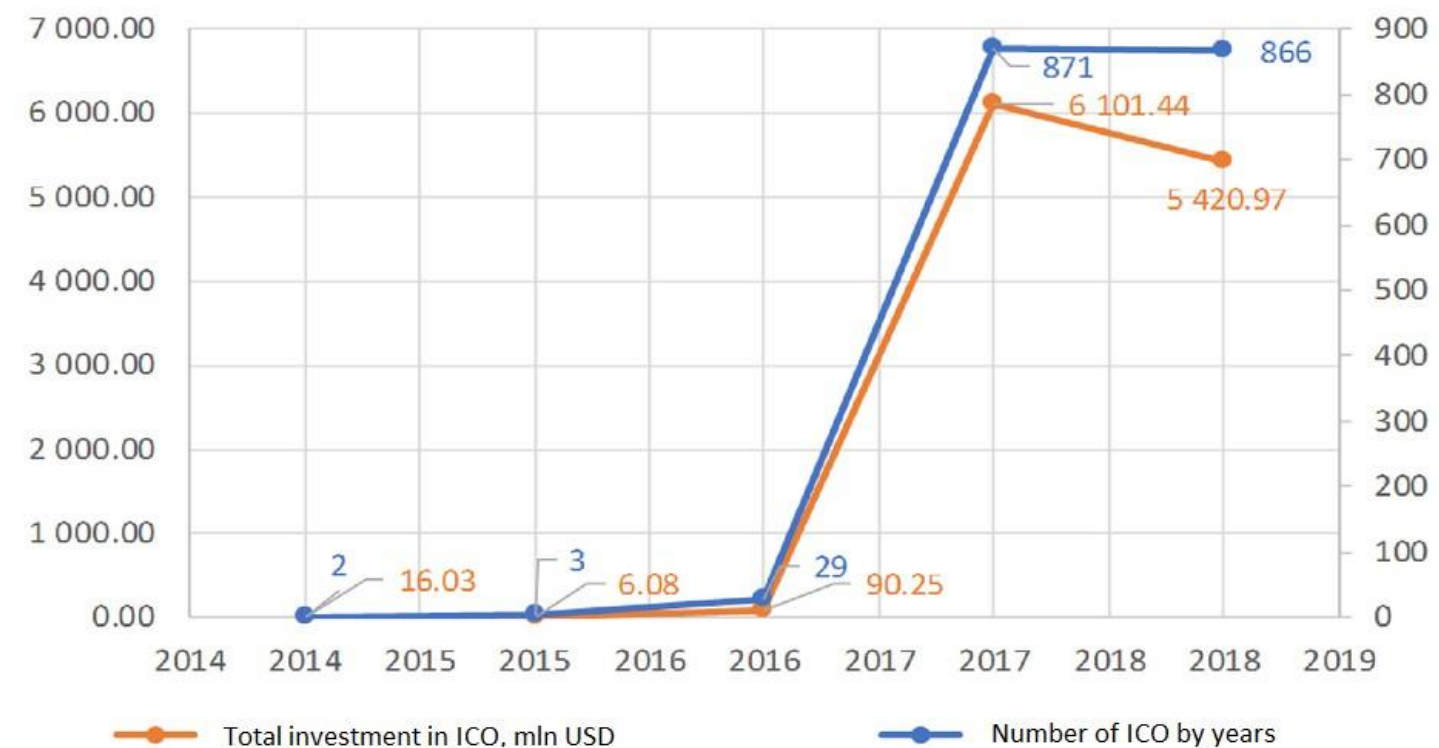

Fig. 1. Successful ICO

Moreover, we can't include this indicator in the classical investment and securities market, as most countries currently do not have the regulation of ICO and their product tokens and coins, as opposed to the long and well-regulated IPO market and their derivatives: stocks, bonds, corporate bonds.

Even more incredible is the comparison of the payback of fixed assets of the classical economy and cryptography.

The figure shows that, on a global scale, US \$ 6 billion is a huge investment in ICO.

Of course, such chances involve the most diverse origin of capital, including uncertain origin, probable and criminal. From available sources it is clear that at present the main investments in the cryptindustry are:

- mining;

- creation of information infrastructure;

- investment in human capital.

ICO-industry in 2017 - the beginning of 2018 was at the stage of absolute boom. This is evidenced by the diversity of projects and the volume of borrowed funds.

The main problems of investing in cryptographic industry can be divided into three groups:

a) group of problems of legislation and legal responsibility of market participants;

b) a group of problems of professional responsibility of market players, experts; 
c) group of problems of a speculative trend.

It is known that only a few countries took up the legislative framework of the crypt industry, taxation and market participants' qualifications. The main thing is the responsibility of such categories as crypto banks, cryptographic, cryptographic funds. Since their financial responsibility, ethics and discipline depend not only on the welfare of millions of investors, but in general, trust in the industry and its survival. By the middle of 2018, the most favorable, safe and regulated countries for ICO and crypto business, according to a study by Hacker Noon, included:

- Singapore;

- Switzerland;

- Cayman Islands;

- USA;

- UK.

ICO Watch List also has statistics on:

- Estonia;

- Belarus;

- Malta;

- Japan.

As for experts and experts, it is clear that in a few years, neither the criteria of expertise nor the experts themselves could be formed. At the moment, there are indisputable leaders in the industry, rather than visionaries, gurus, seers and forecasters. The most famous names of people in the crypto world:

- a collective image or a real person is not yet known - Satoshi Nakamoto - project bitkoniny;

- Vitaliy Butterin - Efirium project;
- Pavlo Durov - Telegram;

- Jihan Wu - Mainging;

- Brian Armstrong;

- Olaf Carlson;

- Tyler and Cameron Winnkowoss;

- Charlie Lee - Lightbox.

And the main problem of the industry is the weak integration with production opportunities, with labor resources and state and intergovernmental structures. The market of cryptographic industry, as it were, is closed to itself, satisfies the demand of the market itself (with some exceptions) and serves the benefit not to systemic investors, but to speculators and outsiders.

Like the classical revolution, and the crypto revolution, the arm is not the smartest and noble investors, but the most greedy, agile and unprincipled. However, you can reliably state that there is a process of systematization and self-cleaning of the market. This is evidenced by a sharp decrease in the number of scams, as well as the pseudo ICO itself, and the number of careless investors.

As of mid-2018, the main investors in the cryptindustry are not market professionals, the socalled whales, people who are trying to simplify, often without thoughtful steps, to increase their income by speculative, passive method. Such unskilled investors are called "hamster". They are the most losing money on fraudulent ICO, on the formation of wrong portfolios. And thus it destabilizes the market and reduces the trust in it.

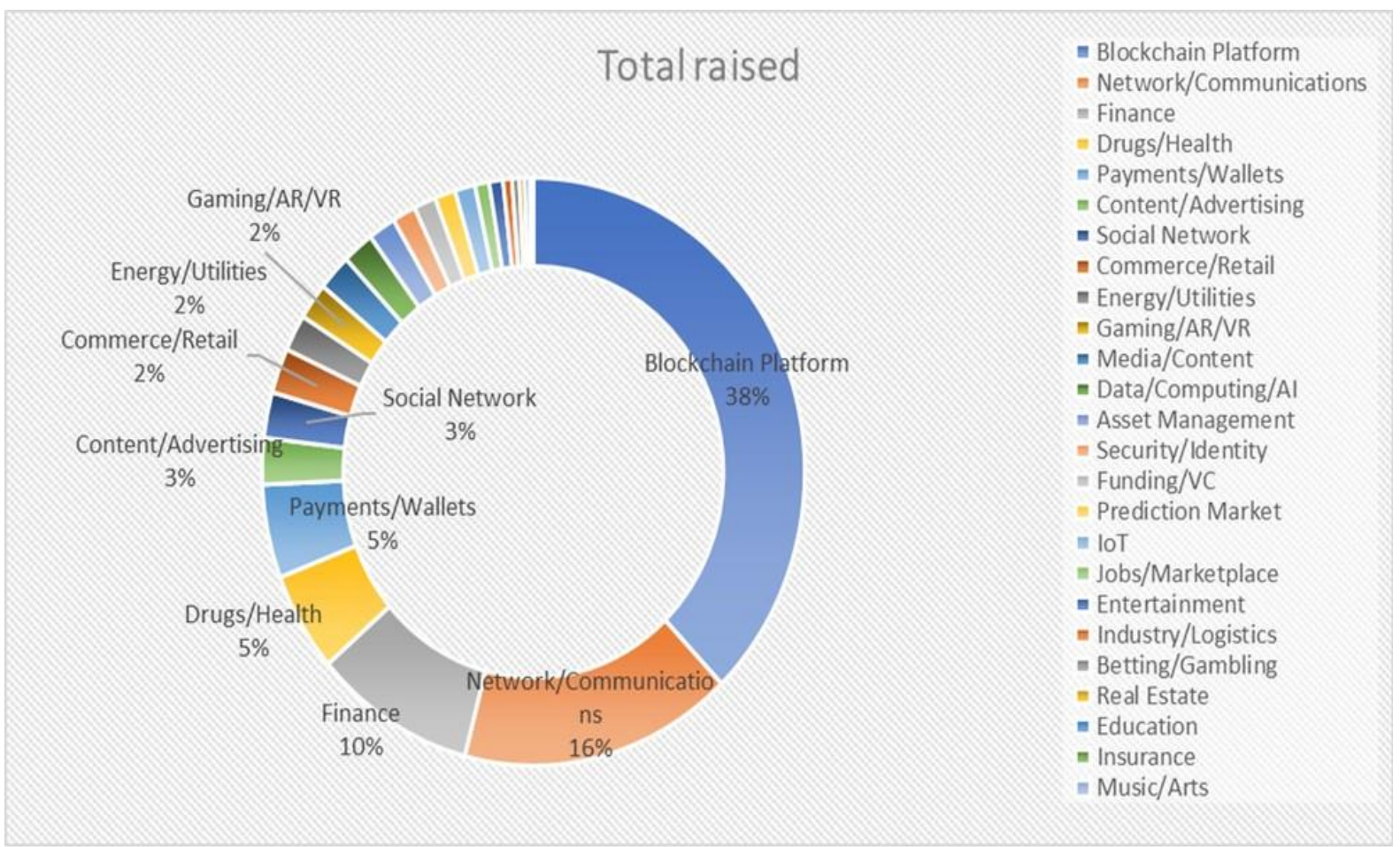

Fig. 2. Distribution of projects that came to ICO by industry

Professional private investors, as a rule, do not risk all their assets using crypto tools like diversification. More studying documents of projects. Using mid-term and long-term investment strategies.
At the end of August 2017, the Forbes magazine published a sample of the 5 largest ICOs, on which it is possible to judge the collective portrait of their investors. 
The data on the payment received on the smart contracts of these projects and only in Etherium was analyzed. The following participated in the sample:

- "Status" - collected 192,000,000 US dollars / total 22,770 people;

- "Bancor" - collected 73000000 USD (with BTC and others - 153000000 \$) / total 10117 persons;

- "Tezos" - collected 102000000 US dollars / total 11368 people;

- Aragon - \$ 82,000,000 / total 2,394 people;

- "DAO. Casino" - collected \$11,000,000 / total 5,363 people.

Thus, the average investor invested in each project the following money:

- Aragon - \$34,460;

- Tezos - \$ 8,988;

- "Status" - \$ 8,438;

- "Bancor" - \$7,191;

- "DAO. Casino" - \$ 2,200 [3].

The main advantages and prospects for Ukraine in the investment market in the cryptographic industry at this stage are:

- the possibility of multiplication of capital. In the language of cryptodustrii - to make an ix (investing in coins and markers, cryptoporphes);

- to occupy a niche, which does not give big profits, but it gives recognition, name and trust of investors (crypto banks, cryptographic funds, etc.);

- diversify other investments with a high level of income and risk expectations (mutual funds, assets in volatile markets, etc.);

- transfer capital of classical investment to other territories without the use of a banking network.

Currently, there are no laws in Ukraine that would regulate cryptographic systems. There are different opinions among experts and politicians: from the complete lack of control, as in most countries, to the ban, as in China.

However, the most rational approach may be the symbiosis of deep regulation, as in the United States, Switzerland, Japan, and flexible opportunities, as in Malleux and in Estonia, with the establishment of a favorable tax climate, as in Belarus and other countries.

Ukrainian market experts offer:

- the zero rate of taxes on the growth of cryptographic capital until it is withdrawn into financial instruments;

- to recognize investments in crypt, mining, etc. types of economic activity with application of reduced tax rates for the period of formation of the market 10 20 years;

- recognize investments in cryptographic instruments by analogy with classic investing;

- to permit the movement of cryptonevesties and cryptographic capital without the obligatory application of traditional channels of transfer of capital, but only with the help of blockade.

In classical financial management, the movement of capital has 4 characteristics:

- purpose of the capital;

- presence of donor country and recipient country;

- reflection in the balance of ownership;
- long-term character [4, p. 67].

Prospects for investing in cryptosystems depend on a huge number of factors. At the moment, there are no substantiated long-term or even medium-term forecasts. But for Ukraine there are prospects for a young market to take a niche using a differentiated idea:

- guarantees to varying degrees for taxpayers in Ukraine, by analogy with Switzerland, the USA, and Germany;

- cryptophoshor or territory of loyalty, by analogy with Estonia, Malta, Singapore;

- the territory of property, by analogy with Iceland, Russia, Kazakhstan.

The modern investment world is mobile, responsive and ready for multi-level forms of cooperation. It is a chance to establish itself in specialization and cooperation for private investors, as well as for countries, including for Ukraine.

\section{References}

1. Murphy H. Threats and opportunities when in cryptocurrencies / Murphy Hannah // Businessjornal. 2017. - № 29. - 22 c.

2. Rumjancev A. P. Mizhnarodna ekonomika (International Economics), Tsentr uchbovoi literatury, 2007, p. 296 (in Ukr.).

3. Golos.Io / Kriptoinvestory: kto oni [Elektronnyi resurs]. - Rezhim dostupa: https://golos.io/ru-apvot50-50/@dickinson-junior/kriptoinvestory-ktooni.

4. Tarasevych V.M. Economichna teoriia. Mizhnarodna ekonomika (Economic theory. International Economics), Znannia, 2012, p.143 (in Ukr.).

5. The Blockchain Review / How to do an Initial Coin Offering (Part 3) [Elektronnyi resurs]. - Rezhim dostupa: https://medium.com/blockchain-review/howto-choose-the-best-jurisdiction-for-an-initial-coinoffering-e95ed4d59177.

6. Coindex / The State of ICO Regulation? New Report Outlines Legal Status in Nations [Elektronnyi resurs]. - $\quad$ Rezhim dostupa: https://www.coindesk.com/state-ico-regulation-newreport-outlines-legal-status-6-nations/.

7. Reed Smith: Driving progress through partnership / SEC Exercises Jurisdiction over Initial Coin Offerings [Elektronnyi resurs]. - Rezhim dostupa: https://www.reedsmith.com/en/perspectives/2017/07/sec-exercises-jurisdiction-over-initialcoin-offerings.

8. Quora / How are initial coin offerings regulated [Elektronnyi resurs]. - Rezhim dostupa: https://www.quora.com/How-are-initial-coin-offerings-regulated

9. Forklog / How to hold the ICO and not violate the law [Elektronnyi resurs]. - Rezhim dostupa: https://forklog.com/kak-provesti-ico-i-ne-narushit-zakon/.

10. Coin telegraph: The future of money / China Ban on ICO is Temporary, Licensing to be Introduced: Official [Elektronnyi resurs]. - Rezhim dostupa: https://cointelegraph.com/news/china-ban-on-ico-istemporary-licensing-to-be-introduced-official. 